\title{
Effect of Combining Fiber and Textile Reinforcement on the Flexural Behavior of UHPC Plates
}

\author{
Tamás Mészöly (i), Sandra Ofner, and Norbert Randl \\ Department of Civil Engineering and Architecture, Carinthia University of Applied Sciences, Spittal an der Drau, Austria \\ Correspondence should be addressed to Tamás Mészöly; meszoely@cuas.at
}

Received 24 April 2020; Revised 28 August 2020; Accepted 14 September 2020; Published 29 September 2020

Academic Editor: Zhiping Luo

Copyright ( $) 2020$ Tamás Mészöly et al. This is an open access article distributed under the Creative Commons Attribution License, which permits unrestricted use, distribution, and reproduction in any medium, provided the original work is properly cited.

\begin{abstract}
A series of flexural tests were performed in order to investigate the effect of steel fiber reinforcement (SFR) in textile-reinforced concrete (TRC) plates. Some of the specimens were reinforced only with textile, some of them only with fibers, and some of them were provided with both textile and fiber reinforcement. The concrete matrix was a self-developed ultrahigh performance concrete (UHPC) mixture with a compression strength over $160 \mathrm{MPa}$. The tensile strength of the used textiles was around $1500 \mathrm{MPa}$ for glass fiber textile and over $3000 \mathrm{MPa}$ for carbon fiber textile. In case of fiber reinforcement, the concrete was reinforced with 2 vol\% of $15 \mathrm{~mm}$ long and $0.2 \mathrm{~mm}$ diameter plain high strength steel fibers. The dimensions of the rectangular plate test specimens were $700 \times 150 \times 30 \mathrm{~mm}$. The plate specimens were tested in a symmetric four-point bending setup with a universal testing machine. The tests were monitored using a photogrammetric measurement system with digital image correlation (DIC). The paper presents and evaluates the test results, analyses the crack patterns and crack development, and compares the failure modes. The results showed a general advantageous mechanical behavior of specimens reinforced with the combination of fibers and textiles in comparison to the specimens reinforced with only fiber or textile reinforcement.
\end{abstract}

\section{Introduction}

Ultrahigh performance concrete has been developed since the 1990s and offers an outstanding compression strength of higher than $150 \mathrm{MPa}$, which is multiple times higher than in case of normal strength concrete (NSC) [1]. To reach the extraordinary kind of strength, a very fine and dense structure is needed, which contains a proper combination of finest compounds such as quartz powder, microsilica, and cement. Because of the high packing density, UHPC has a matrix almost free of capillary pores, which makes the material nearly resistant to chloride ingression, alkali, and deicing salt. With a partly substitution of cement in the mixture, for example, with fly ash or blast furnace slag, an almost identical compressive strength without any degradation of the mechanical properties and workability parameters can be reached [2-5]. Including these facts and the material-savings potential due to the high compressive strength and the smaller necessary concrete cover, UHPC can be rated as material-saving and durable building material with a lower ecological impact than NSC $[5,6]$.
Due to the high packing density, UHPC has a very brittle behavior under compression loading. Therefore, usually steel fibers are added in the mixture to avoid this negative behavior. By adding fibers, ultrahigh performance fiberreinforced concrete (UHPFRC) is able to resist notable tensile forces [7], and it provides a more ductile behavior. Moreover, fibers can significantly increase the shear resistance of UHPC beams [8], or prefabricated UHPFRC units can be applied for local strengthening of highly compressed concrete zones [9]. When using fiber-reinforced concrete, the fiber orientation and distribution have a strong impact on the tensile behavior. These attributes are influenced not only by the production and the pouring of the concrete but also by depending on the shape and size of the specimens [10].

The demand of a more predictable structural response leads to the idea to combine UHPC with textile reinforcement. In addition to the other outstanding features of UHPC, a very high bond strength to reinforcing materials can be developed [11]. Typical materials for textile reinforcements are alkali-resistant (AR) glass or carbon. These 
materials show besides their high tensile strength (up to 5 times the tensile strength of ordinary reinforcement steel) and sufficient ultimate strain, an adequate modulus of elasticity and a low relaxation and resistance to corrosion in alkaline environment and in concrete $[12,13]$. Above all, it can be placed exactly in the direction and where it is needed, which beneficially affects the failure mechanism and the ductility of the concrete structure $[13,14]$.

Textile reinforcement is made of rovings, which are bundles of infinite filaments. These filaments are glued together with an impregnation made of epoxy (EP) or styrenebutadiene (SB). The impregnation leads to an activation of the inner core of filaments in the roving, which is important to get a uniform stress distribution over the whole crosssection of the bundle [15]. The rovings are connected by means of knitting threads at the crossing points, which has an essential effect on the composite bearing capacity of the fabrics [14].

Due to the small mesh sizes of the usually used plane textile reinforcement, only fine grain concrete mixes and mortars with a maximum grain size of $4 \mathrm{~mm}$ are used. For rigid $\mathrm{EP}$ impregnated textiles, the maximum grain size of the used concrete can go up to $8 \mathrm{~mm}$. Therefore, UHPC with its grain size of usually less than $4 \mathrm{~mm}$ is an optimal material for this composition.

Regarding aspects of sustainability, it can be mentioned, that the high resistance to corrosion of textile reinforcement can lead to a reduced concrete cover, which means that the cross-section of structural components can be reduced as well. Several studies are dealing with the sustainability of the textile reinforcement $[16,17]$. Furthermore, the recycling of textile-reinforced concrete, when comparing with ordinary steel-reinforced or fiber-reinforced concrete, with respect to separation of textile and surrounding concrete matrix, is relatively easy $[18,19]$.

\section{Materials and Methods}

The ongoing project investigates and compares the following types of material combinations:

(i) UHPC with steel fibers

(ii) UHPC with textile reinforcement

(iii) UHPC with steel fibers and textile reinforcement

The paper presents and evaluates the test results, analyses the crack patterns and the crack development, and compares the failure modes.

2.1. Materials. The used textiles are epoxy-coated carbon and AR-glass textiles produced by the Solidian company. The distance of the rovings is the same $38 \mathrm{~mm}$ into the two horizontal directions, and the rovings have the same crosssectional area into the two main directions. The main geometrical and mechanical properties of the textiles are summarized in Table 1.

The used fibers are commercial products manufactured from high strength steel wires. The fibers are straight by their product description but slightly curved in practice, with a circular cross-section. They are coated with brass for corrosion protection. The main geometrical and mechanical properties of the fibers are summarized in Table 2.

The specimens were produced using a self-developed UHPC mixture either without fibers or with a fiber content of $2 \%$ by volume. Table 3 presents the mixture proportions of the applied UHPC and UHPFRC materials. The maximum grain size of the quartz sand was $0.4 \mathrm{~mm}$. The mean compression strengths of the mixtures are in the range of $165 \mathrm{MPa}$ and $180 \mathrm{MPa}$ measured on cubes 28 days after casting. A summary of the main characteristics of the mixtures can be found in Table 4 .

2.2. Methods. To determine the load bearing behavior of the different material combinations of UHPC with textile and fiber reinforcement, bending tests were performed following the recommendation of Kulas [12]. The test specimens were produced with the dimensions length $\times$ width $\times$ thickness equal to $700 \times 150 \times 30 \mathrm{~mm}$. The textile reinforcement layer was placed $10 \mathrm{~mm}$ from the bottom surface and $20 \mathrm{~mm}$ from the top surface of the specimens, which was ensured with a two-part formwork. The warp direction of the textile was orientated in longitudinal direction to the axis of the specimen. Three specimens were produced, tested, and evaluated for each combination. The specimens were tested in a symmetric four-point bending test setup with a span of $600 \mathrm{~mm}$. The test setup can be seen in Figure 1:

\section{Results and Discussion}

3.1. Load-Deflection Curves. Figure 2 depicts a comparison of the load-deflection curves derived from four-point bending tests. Figure 2(a) depicts a comparison of test results with carbon textile-reinforced UHPC, carbon textile-reinforced UHPFRC, and UHPFRC. The graphs show that the initial stiffness of the composites is very similar. After the first crack, carbon textile-reinforced UHPC plates exhibit strong drops in the load value at each new crack: after the crack appears, the specimen loses more than half of its load; then, the load level increases until the next crack appears at a slightly higher load level. This slow increase and sudden dropping behavior becomes less dominant later on, as more and more the textile reinforcement holds the load and drives the overall structural behavior.

In contrast, UHPFRC plates lose their initial stiffness gradually, without any pronounced load drop, and after the peak load, also the descending branch of the curve shows a gradual load decrease during the pull-out of the fiber reinforcement. The first crack at carbon textile-reinforced UHPFRC plates results in a significant stiffness change without a load drop. After that, the structural stiffness decreases gradually, but this change is not significant. Furthermore, the curves do not show any significant load dropping until the ultimate load.

Figure 2(b) depicts the comparison of the load versus deflection curves with glass textile-reinforced UHPC, UHPFRC, and UHPFRC without textile. The glass textile- 
TABLE 1: Main properties of the used textiles (producer's data sheet).

\begin{tabular}{lccccc}
\hline Used textiles & $\begin{array}{c}\text { Cross-sectional area of } \\
\text { rovings }\left(\mathrm{mm}^{2}\right)\end{array}$ & $\begin{array}{c}\text { Axial distance } \\
(\mathrm{mm})\end{array}$ & $\begin{array}{c}\text { Cross-sectional area of } \\
\text { reinforcement }\left(\mathrm{mm}^{2} / \mathrm{m}\right)\end{array}$ & $\begin{array}{c}\text { Young's } \\
\text { modulus }(\mathrm{GPa})\end{array}$ & $\begin{array}{c}\text { Tensile strength }(\mathrm{mean} \\
\text { value })(\mathrm{MPa})\end{array}$ \\
\hline $\begin{array}{l}\text { Solidian GRID } \\
\begin{array}{l}\text { Q95/95-CCE-38 } \\
\text { Solidian GRID }\end{array}\end{array}$ & 3.62 & 38 & 95 & 220 & 3200 \\
Q97/97-AAE-38 & 3.68 & 38 & 97 & 72 & 1550 \\
\hline
\end{tabular}

TABLE 2: Main properties of the used steel fibers (producer's data sheet).

\begin{tabular}{lccccc}
\hline Used fibers & Length $(\mathrm{mm})$ & Diameter $(\mathrm{mm})$ & Length/diameter $(-)$ & Young's modulus $(\mathrm{GPa})$ & $\begin{array}{c}\text { Tensile strength } \\
(\mathrm{mean} \text { value })(\mathrm{MPa})\end{array}$ \\
\hline Stratec Weidacon FM $0.20 / 15$ & 15 & 0.2 & 75 & 200 & $>2000$ \\
\hline
\end{tabular}

TABLE 3: Mixture proportions of the applied UHPC and UHPFRC materials $\left(\mathrm{in} \mathrm{kg} / \mathrm{m}^{3}\right.$ ).

\begin{tabular}{lcc}
\hline Ingredient & UHPC & UHPFRC \\
\hline Cement & 867 & 850 \\
Sand & 883 & 865 \\
Microsilica & 146 & 143 \\
Quartz powder & 250 & 245 \\
Water & 199 & 195 \\
Superplasticizer & 20 & 20 \\
Fiber & 0 & 157 \\
\hline
\end{tabular}

TABLE 4: Main properties of the used UHPC and UHPFRC mixtures 28 days after casting.

\begin{tabular}{lccccc}
\hline $\begin{array}{l}\text { Used } \\
\text { mixtures }\end{array}$ & $\begin{array}{c}\text { Compression strength } \\
(\mathrm{MPa})\end{array}$ & $\begin{array}{c}\text { Splitting tensile strength } \\
(\mathrm{MPa})\end{array}$ & $\begin{array}{c}\text { Young's modulus } \\
(\mathrm{GPa})\end{array}$ & $\begin{array}{c}\text { Maximum grain size } \\
(\mathrm{mm})\end{array}$ & $\begin{array}{c}\text { Fiber content (vol } \\
\%)\end{array}$ \\
\hline UHPC & 166.3 & 7.9 & 44.7 & 0.4 & 0 \\
UHPFRC & 172.5 & 16.1 & 49.3 & 0.4 & 2 \\
\hline
\end{tabular}

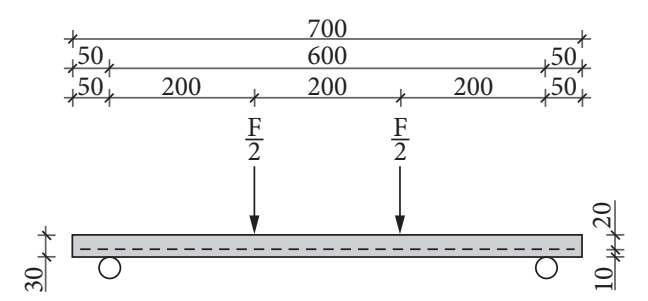

(a)

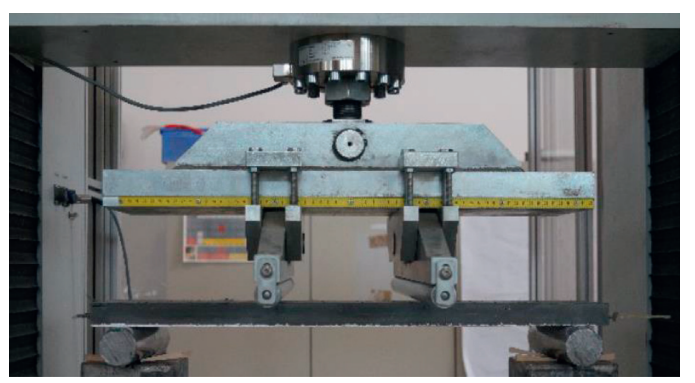

(b)

FIgURE 1: (a) Dimensions of the specimen and the test setup (mm). (b) The test setup during testing.

reinforced UHPC plates behave similar to the carbon textilereinforced ones: they show pronounced repetitive load drops and increases during cracking. The increase of the peak load between these local maximums is, however, smaller, and the overall structural stiffness is lower, which is attributed to the significantly lower stiffness of the glass textile (Table 1). The characteristics of the load vs. deflection curves of glass textile-reinforced UHPFRC plates are similar to the carbon textile-reinforced UHPFRC: after the first crack, there are only few smaller load drops, while the structural stiffness decreases gradually. The second part of the curves (considering deflections between $10 \mathrm{~mm}$ and $30-35 \mathrm{~mm}$ ) is close to linear, and it is determined by the properties of the glass textile.

Comparing the three types of plates generally, the textilereinforced UHPC has the lowest structural stiffness because of its repetitive load dropping behavior, the textile-reinforced UHPFRC shows significantly higher structural stiffness, and the UHPFRC shows the highest one, but that stiffness declines continuously because of the cracking 


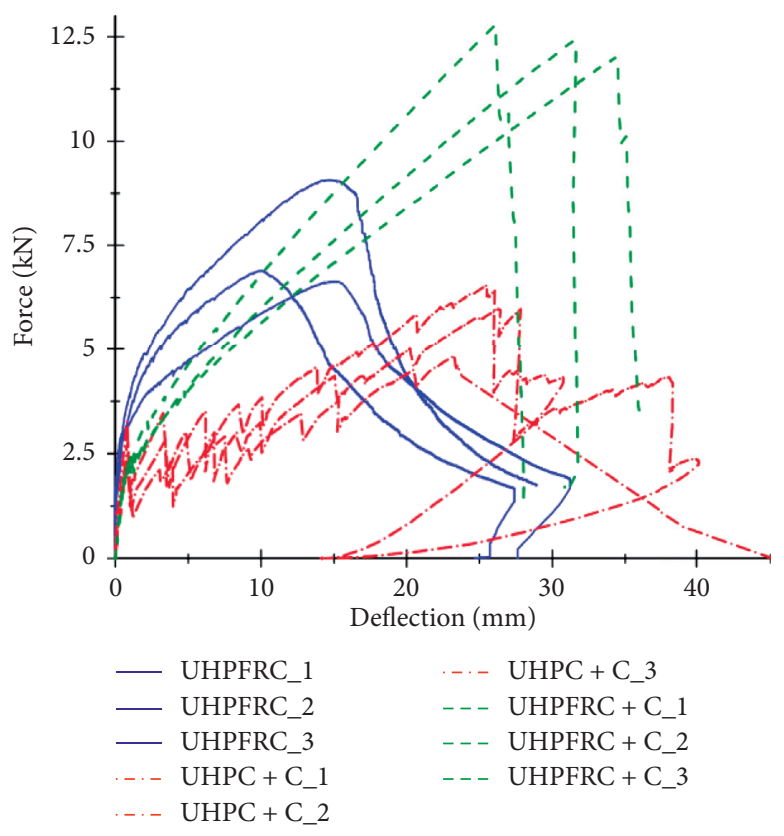

(a)

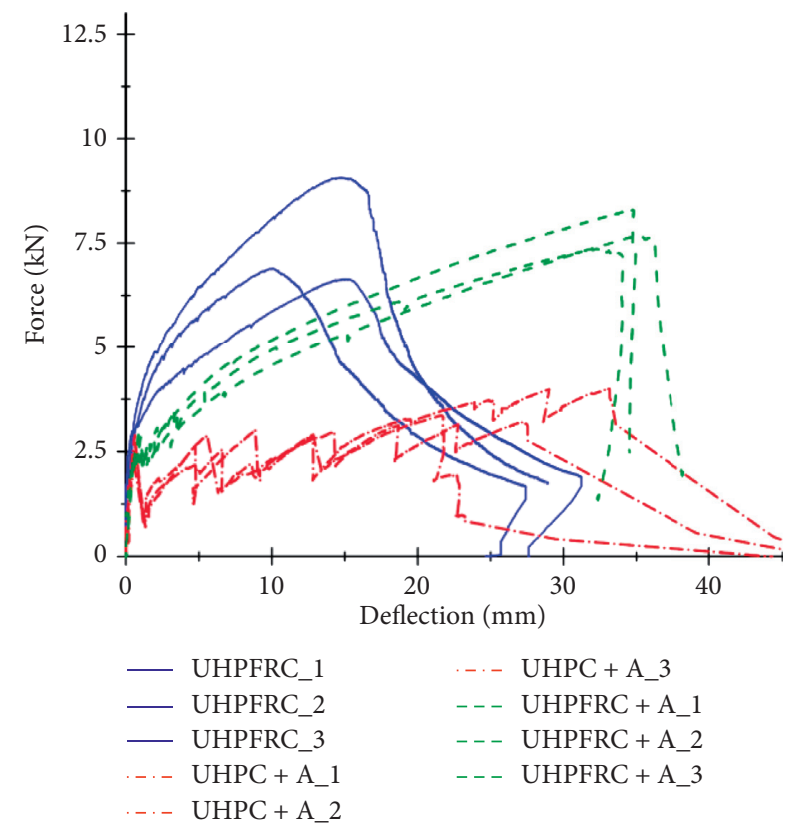

(b)

FIGURE 2: Comparison of load-deflection curves by using UHPC and UHPFRC with and without (a) carbon textile and (b) glass textile.

process. The tests approved that fiber reinforcement can effectively help textile-reinforced plates in the first part of the loading process (where the repetitive cracking of the concrete matrix drives the structural behavior) by bridging the cracks and limiting the crack opening, while the textile reinforcement can effectively hold larger loads, at a stage where the fiber reinforcement would reach its deformation capacity by pull-out without the textile.

Failure modes of the different plates are different as well. The UHPFRC plates have no well-defined failure point: after the ultimate load, the load slowly decreases with the increasing deflection, and the cracks open wider, but the specimens stay intact and can hold the residual load. The textile-reinforced UHPC plates split at maximum load in a way, that part of the concrete cover drops down (delamination), and then, later at even larger deformations, the textile breaks. In contrast, textile-reinforced UHPFRC plates do not show any sign of delamination. The load increases linearly with increasing deformation, the cracks open wider, until the textile reaches its failure and suddenly breaks.

While the scatter of the ultimate load is quite large in case of UHPFRC plates, it is relatively smaller with textilereinforced UHPC plates and low with textile-reinforced UHPFRC plates. Similarly, the scatter of the deformation at the ultimate load is relatively large in the case of UHPFRC and textile-reinforced UHPC plates, but it is smaller at textile-reinforced UHPFRC plates.

Table 5 summarizes the main parameters of the load versus deflection curves: the mean ultimate load values, the mean deflection at the ultimate load, and the mean measured deflection just before final failure. Final failure of the specimen was reached when it collapsed or could not hold the load anymore, with the exception of UHPFRC plates, where there is no definite loss of load bearing capacity. The numbers show, that the textile-reinforced UHPC fails at the lowest load: $3.5 \mathrm{kN}$ at glass textile-reinforced plates and $5.8 \mathrm{kN}$ at carbon textile-reinforced plates in the performed tests. The UHPFRC plates can hold higher loads around $7.5 \mathrm{kN}$ on average. Combining textile and fiber reinforcement more than doubles the ultimate load compared with specimens only with textile reinforcement: $7.8 \mathrm{kN}$ with glass textile (123\% increase) and $12.4 \mathrm{kN}$ with carbon textile $(114 \%$ increase). Compared with only fiber-reinforced plates, the increase is only $4 \%$ in the case of glass textile and $65 \%$ in case of carbon textile. This means that the glass textile with its low load bearing capacity and stiffness cannot help effectively the UHPFRC plate, while interaction of carbon textile reinforcement with UHPFRC results in almost addition of the load bearing capacities of the two types of reinforcement $(12.4 \mathrm{kN}$ vs. $13.3 \mathrm{kN})$.

The deflection values in Table 5 show that UHPFRC plates reach their ultimate load at only $13.3 \mathrm{~mm}$ on average, while this value is almost doubling with textile-reinforced UHPC and almost two and a half times higher with textilereinforced UHPFRC. Comparing the deflection values of textile-reinforced plates at the ultimate load, the presence of fibers increases this value by $48 \%$ for glass textile-reinforced plates and by $20 \%$ for carbon textile-reinforced plates. Mean deflection values before failure show that textile-reinforced UHPC plates fail at about $22 \%$ higher deflection compared to the deflection at the ultimate load, while textile-reinforced UHPFRC plates fail at only about $2 \%$ higher deflection. This means that textile-reinforced UHPFRC plates fail close to their peak load and behave less ductile than the same plates without fibers. On the other hand, this failure happens at least at two times higher load. In case of UHPFRC plates, 
Table 5: Key values of the load-deflection curves.

\begin{tabular}{lccc}
\hline Specimen types & Mean max load $(\mathrm{kN})$ & Mean deflection at the ultimate load $(\mathrm{mm})$ & Mean deflection before failure $(\mathrm{mm})$ \\
\hline UHPFRC & 7.5 & 13.3 & $(28.8)$ \\
UHPC + glass textile & 3.5 & 23.1 & 28.0 \\
UHPC + carbon textile & 5.8 & 25.6 & 31.5 \\
UHPFRC + glass textile & 7.8 & 34.1 & 35.1 \\
UHPFRC + carbon textile & 12.4 & 30.8 & 31.3 \\
\hline
\end{tabular}

there is no well-defined failure point because at a slowly decreasing load level, it can reach three to five times higher deformations than observed at the ultimate load. The $28.8 \mathrm{~mm}$ deflection value in Table 5 is the point where the tests were stopped (on average), which is 2.2 times the deformation compared with its value at the ultimate load, but the specimens are not broken at that point. The measured values show that glass textile-reinforced UHPC plates fail at $12 \%$ lower deformation than carbon textile-reinforced UHPC plates, despite of the higher ultimate strain of the glass textile compared to carbon textile (around $2.0 \%$ vs. $1.5 \%$ ), while the textiles do not reach their ultimate tensile strength neither. This observation fits to earlier experiences described in Mészöly et al. [20], and it is likely due to the transversal forces and damages in the textile caused by the cracked concrete. In comparison, glass textile-reinforced UHPFRC plates fail at $12 \%$ higher deformation than carbon textile-reinforced UHPFRC plates. The glass textile-reinforced plates can take the advantage of the fiber contribution (25\% increase compared to the same plates without fibers), which results in a denser crack pattern, smaller crack opening values, and the consequently smaller transversal forces on the textile. In contrast, the carbon textile-reinforced UHPFRC plates fail at the same deflection level than the same plates without fibers.

3.2. Crack Distribution and Crack Widths. The tests were monitored using a photogrammetric measurement system with digital image correlation (DIC). With the DIC system, it is possible to observe and monitor the surface deformations, the crack pattern of the specimens, and measure the crack opening of every single crack with an accuracy of about one $\mu \mathrm{m}$ or the strain can be derived on the specified measurement range. Such type of measurement provides several advantages to traditional equipment: for example, the formation of cracks leads to a failure of attached strain gauges, whereas displacement transducers can only deliver information about a certain observation length and its total elongation; moreover, during abrupt rupture of a specimen, displacement transducers can be damaged. The DIC system allows on the other hand to monitor the full process from first loading to even after-peak behavior of a tested specimen. Table 6 summarizes some key values derived from the crack evaluation.

The first investigated value is the load where the first crack appears, which is defined where the largest crack mouth opening displacement (CMOD) reaches $0.01 \mathrm{~mm}$. This parameter is the largest at UHPFRC plates, reaching $3.0 \mathrm{kN}$ on average. The same parameter for textile-reinforced
UHPC plates is a little bit lower, $2.7 \mathrm{kN}$ with glass textile, and $2.8 \mathrm{kN}$ with carbon textile. Surprisingly, it is significantly lower for textile-reinforced UHPFRC plates, $2.1 \mathrm{kN}$ with the glass textile and only $1.8 \mathrm{kN}$ with the carbon textile. By backcalculating the tensile stress in the bottom surface of UHPC plates at the moment where the first crack appears, the tensile strength can be estimated. Based on the test results, it is $8.6 \mathrm{MPa}$ on average, which is comparable with the measured splitting tensile strength of $7.9 \mathrm{MPa}$ in Table 2 .

The second investigated parameter is the load where the largest CMOD reaches $0.1 \mathrm{~mm}$. Beside the load values summarized in Table 5, Figure 3 presents the crack pattern of the specimens when the largest crack reaches $0.1 \mathrm{~mm}$. Figure 3(a) shows that the crack pattern is very dense at UHPFRC plates when the largest crack reaches $0.1 \mathrm{~mm}$ CMOD value: the plates depict $50-100$ very small hairline cracks, which fill out the plate surface like a net. The UHPFRC plates hold $6.0 \mathrm{kN}$ load at that phase. In case of UHPC plates (reinforced with glass or carbon textile, Figure 3(b) and 3(c)), the first crack opens wide abruptly $(0.20 \mathrm{~mm}$ at $2.7 \mathrm{kN}$ in case of glass textile and $0.15 \mathrm{~mm}$ at $2.8 \mathrm{kN}$ in case of carbon textile-reinforced plates, in the moment when the first crack started to form). In comparison, fibers can effectively limit the opening of the cracks in case of plates reinforced with both fibers and textile: the cracks remain very small at the beginning, and then, they open wider at higher loads. As a result, when the largest crack reaches $0.1 \mathrm{~mm}$ at a significantly higher load level ( $3.4 \mathrm{kN}$ for glass textile-reinforced UHPFRC and $3.8 \mathrm{kN}$ for carbon textile-reinforced UHPFRC), there are already several similar cracks, Figures 3(d) and 3(e).

The third parameter is the CMOD value at a load level of $5 \mathrm{kN}$. Table 5 presents both the values of the largest crack width at $5 \mathrm{kN}$ load and the typical, mean crack width value at $5 \mathrm{kN}$, and Figure 4 compares the crack patterns at $5.0 \mathrm{kN}$ load level. The UHPFRC plates have 20-30 hairline cracks (Figure 4(a)). The largest crack opening values are measured between $30 \mu \mathrm{m}$ and $60 \mu \mathrm{m}$, and the mean values are only between $10 \mu \mathrm{m}$ and $30 \mu \mathrm{m}$. The shapes of the cracks are less regular and straight than observed at textile-reinforced plates. The glass textile-reinforced UHPC plates fail at a lower load level ( $3.5 \mathrm{kN}$ in average); therefore, Table 5 gives no value, and there is no image of these plates in Figure 4. The carbon textile-reinforced UHPC plates have 6-7 cracks (Figure 4(b)) with a maximum crack opening of $1.1 \mathrm{~mm}$ and a mean crack opening value of $0.7 \mathrm{~mm}$. These values are 20-50 times higher than the ones recorded with UHPFRC plates. When fibers are provided for textile-reinforced plates, the number of cracks roughly doubles (10-11 cracks for glass textile and 12-13 cracks for carbon textile-reinforced plates, Figures 4(c) and 
TABLE 6: Key values from the crack evaluation.

\begin{tabular}{lcccc}
\hline Specimen types & $\begin{array}{c}\text { First crack appears } \\
(\mathrm{kN})\end{array}$ & $\begin{array}{c}\text { Largest crack reaches } \\
0.1 \mathrm{~mm}(\mathrm{kN})\end{array}$ & $\begin{array}{c}\text { Largest/mean crack } \\
\text { width } \\
\text { at } 5 \mathrm{kN}(\mathrm{mm})\end{array}$ & $\begin{array}{c}\text { Largest crack width at the ultimate } \\
\text { load }(\mathrm{mm})\end{array}$ \\
\hline UHPFRC & 3.0 & 6.0 & $0.05 / 0.02$ & 0.3 \\
UHPC + glass textile & 2.7 & 2.7 & - & $1.1 / 0.70$ \\
UHPC+ carbon textile & 2.8 & 2.8 & $0.34 / 0.20$ & 1.3 \\
UHPFRC+ glass textile & 2.1 & 3.4 & $0.18 / 0.10$ & 1.3 \\
UHPFRC + carbon & 1.8 & 3.8 & 0.9 \\
Textile & & 3.8 & \\
\hline
\end{tabular}

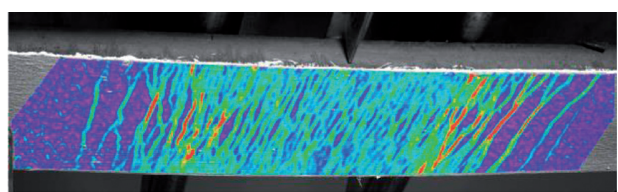

(a)

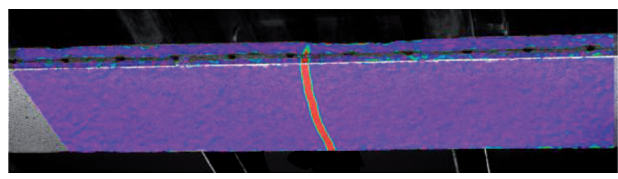

(c)

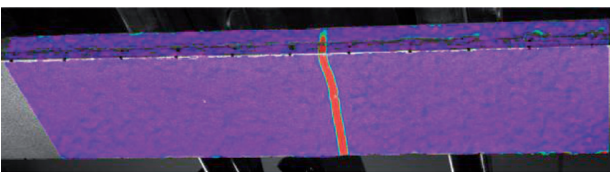

(b)

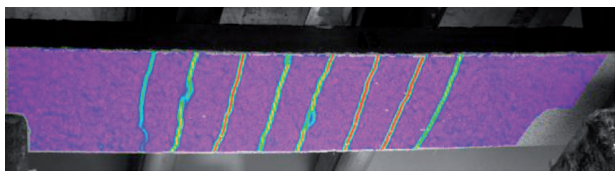

(d)

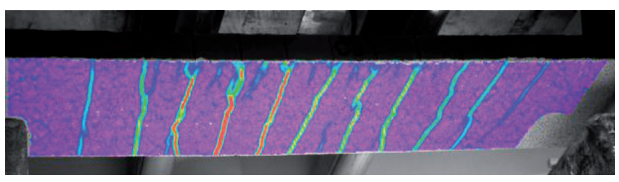

(e)

FIGURE 3: Crack pattern of the specimens at $0.1 \mathrm{~mm}$ crack opening. (a) UHPFRC, (b) UHPC + glass textile, (c) UHPC + carbon textile, (d) $\mathrm{UHPFRC}+$ glass textile, and (e) UHPFRC + carbon textile.

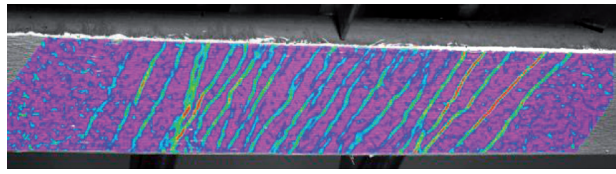

(a)

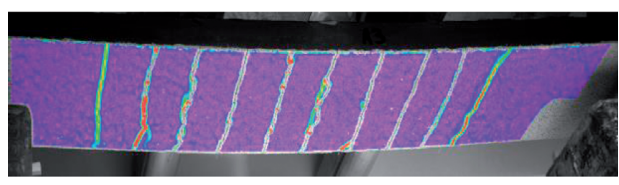

(c)

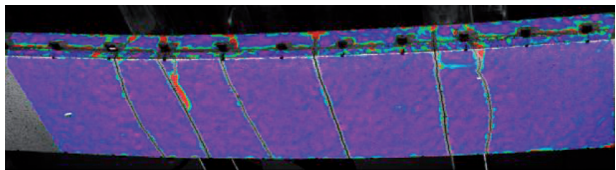

(b)

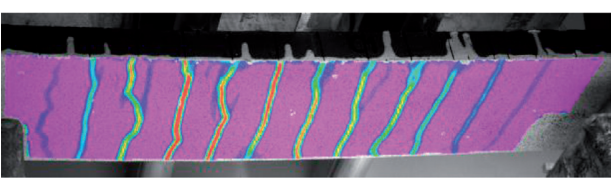

(d)

Figure 4: Crack pattern of the specimens at $5.0 \mathrm{kN}$ load level. (a) UHPFRC, (b) UHPC + carbon textile, (c) UHPFRC + glass textile, and (d) UHPFRC + carbon textile.

4(d)) compared to the numbers observed for the same plates without fibers. With fibers, the plates reinforced with glass textile already reach a load level of $5.0 \mathrm{kN}$ and show a largest crack opening value of $0.34 \mathrm{~mm}$ and a mean crack opening value of $0.20 \mathrm{~mm}$. In comparison, the largest crack opening is $0.18 \mathrm{~mm}$ and the mean crack opening value is $0.10 \mathrm{~mm}$ for carbon textile-reinforced UHPFRC plates. These values are $85 \%$ (with other words 6.6 times) lower than without fibers.

The fourth investigated parameter is the largest CMOD value at the ultimate load level. Based on the test evaluation,
UHPFRC plates depict the smallest crack opening values again: the crack width reached only $0.3 \mathrm{~mm}$ at the maximum load. The largest crack opening was 4.4 times bigger $(1.3 \mathrm{~mm})$ at carbon textile-reinforced UHPC plates and 5.7 times bigger $(1.7 \mathrm{~mm})$ at the glass textile-reinforced UHPC plates. By adding fibers, the largest crack opening of textilereinforced plates at the ultimate load decreases by $25-31 \%$ and reaches $1.3 \mathrm{~mm}$ in case of glass textile-reinforced UHPFC and $0.9 \mathrm{~mm}$ in case of carbon textile-reinforced UHPFRC. Furthermore, it is worth mentioning that the load 
values are 2-2.5 times higher for these specimens than for the ones without fibers.

\section{Conclusions}

The present paper compares the results of flexural tests on plates using UHPFRC, glass or carbon textile-reinforced UHPC, and glass or carbon textile-reinforced UHPFRC and investigates the effect of steel fiber reinforcement in case of textile-reinforced UHPFRC plates. The results back up the following most important conclusions when fibers are provided together with textile reinforcement:

(i) The ultimate load is twice as high when comparing fiber-reinforced to nonfiber-reinforced TRC elements, and the scatter of the ultimate load values is smaller compared to both UHPFRC and TRC plates.

(ii) The pronounced load dropping behavior that is typical for TRC elements can be avoided with the addition of steel fibers, and the load vs. deflection relation is more predictable and close to linear.

(iii) The structural response during the cracking phase is significantly stiffer than the response for TRC elements without steel fibers.

(iv) The deformation capacity and the deflection at the ultimate load are almost two and a half times higher than the respective values for UHPFRC without textile reinforcement.

(v) The cracks remain very small at the beginning, and the further opening is delayed and observed only at higher load levels because the steel fibers are able to effectively limit the opening of the cracks. Furthermore, the number of (smaller) cracks increases, resulting in a more homogeneous stress distribution.

(vi) Both steel fiber and textile-reinforced plates reach the $0.1 \mathrm{~mm}$ crack opening value at more than $30 \%$ higher load than TRC plates.

(vii) At the chosen $5 \mathrm{kN}$ load level, the crack opening values are $85 \%$ lower, and the number of cracks is double than in case of textile-reinforced UHPC plates, and the largest crack openings of TRC plates at the ultimate load decrease by $28 \%$ on average.

Concluding, the present test results verify a general advantageous mechanical behavior of specimens reinforced with the combination of fibers and textiles in comparison to the specimens reinforced with only fiber or textile reinforcement.

\section{Data Availability}

The data used to support this study are included within the article.

\section{Conflicts of Interest}

The authors declare that they have no conflicts of interest.

\section{Acknowledgments}

The authors would like to acknowledge the support of the Austrian Research Promotion Agency (CON_FIT project, grant number 866881). Likewise, the supply of material equipment by the companies Solidian and W\&P is appreciated.

\section{Supplementary Materials}

Datasets of the load-deflection curves in the format of comma-separated values (CSV), are available in the Supplementary Materials. (Supplementary Materials)

\section{References}

[1] P. Richard and M. Cheyrezy, "Composition of reactive powder concretes," Cement and Concrete Research, vol. 25, no. 7, pp. 1501-1511, 1995.

[2] K. Droll, "Influence of additions on ultra high performance concretes-grain size optimisation," in Proceedings of the International Symposium on Ultra High Performance Concrete, Schriftenreihe Baustoffe Und Massivbau, no. 3, pp. 285-301, Kassel University Press, Kassel, Germany, September 2004.

[3] H. Yazıcı, H. Yiğiter, A. S. Karabulut, and B. Baradan, "Utilization of fly ash and ground granulated blast furnace slag as an alternative silica source in reactive powder concrete," Fuel, vol. 87, no. 12, pp. 2401-2407, 2008.

[4] E. Ghafari, H. Costa, E. Júlio, A. Portugal, and L. Durães, "Enhanced durability of ultra high performance concrete by incorporating supplementary cementitious materials," in Proceedings of 2nd International conference on Microstructural-Related Durability of Cementitious Composites, RILEM Pro83, pp. 1422-1430, Amsterdam, The Netherlands, April 2012.

[5] N. Randl, T. Steiner, S. Ofner, E. Baumgartner, and T. Mészöly, "Development of UHPC mixtures from an ecological point of view," Construction and Building Materials, vol. 67, no. Part C, pp. 373-378, 2014.

[6] A. Šajna, E. Denarié, and V. Bras, "Assessment of UHPFRC based bridge rehabilitation in Slovenia, two years after application," in Proceedings of Hipermat 2012-3rd International Symposium on UHPC and Nanotechnology for High Performance Construction Materials, Schriftenreihe Baustoffe Und Massivbau, no. 19, pp. 937-944, Kassel University Press, Kassel, Germany, March 2012.

[7] E. Fehling, M. Schmidt, T. Teichmann, B. Kai, B. Roland, and M. Bernhard, "Entwicklung, dauerhaftigkeit und berechnung ultrahochfester betone (UHPC), DFG-forschungsbericht FE 497/1-1," in Schriftenreihe Baustoffe Und Massivbauno. 1, Kassel University Press, Kassel, Germany, 2005.

[8] T. Mészöly and N. Randl, "Shear behavior of fiber-reinforced ultra-high performance concrete beams," Engineering Structures, vol. 168, pp. 119-127, 2018.

[9] M. Ricker, F. Häusler, and N. Randl, "Punching strength of flat plates reinforced with UHPC and double-headed studs," Engineering Structures, vol. 136, pp. 345-354, 2017.

[10] NF P18-470, Concrete-Ultra-high Performance Fibre-Reinforced Concrete-Specifications, Performance, Production and Conformity, Association Française De Normalisation (AFNOR), Saint-Denis, France, 2016.

[11] D. Č́tek, P. Huňka, S. Řeháček, T. Mandlík, and J. Kolísko, "Testing of bond behavior of UHPC," Advanced Materials Research, vol. 1054, pp. 95-98, 2014. 
[12] O. Bruckermann, "Modelling the tensile behaviour of textile reinfored concrete," Ph.D. thesis, RWTH Aachen, Aachen, Germany, 2007.

[13] M. Curbach and F. Jesse, "Eigenschaften und anwendungen von textilbeton," Beton-Und Stahlbetonbau, vol. 104, no. 1, pp. 9-16, 2009.

[14] RILEM 201-TRC, "Textile reinforced concrete-statef-hert report of RILEM technical committee 201-TRC," in Report 36, W. Brameshuber, Ed., RILEM, Bagneux, France, 2006.

[15] C. H. Kulas, "Loadearing behavior of impregnated textile reinforcements for concrete members," Ph.D. thesis, RWTH Aachen, Aachen, Germany, 2013.

[16] P. Hájek, M. Novotná, A. Chira, C. Fiala, T. Vlach, and L. Laiblová, "Challenge of textile reinforced high performance concrete for sustainable construction," in Proceedings of the Fib Symposium 2015, Copenhagen, Denmark, May 2015.

[17] N. W. Portal, K. Lundgren, H. Wallbaum, and K. Malaga, "Sustainable potential of textile-reinforced concrete," Journal of Materials in Civil Engineering, vol. 27, no. 7, pp. 1-12, 2014.

[18] J. Kortmann, Abbruch, Rückbau und Recycling Von $C^{3}$-Bauteilen, Carbon-Und Textilbetontage, Dresden, Germany, 2017.

[19] S. Ofner, N. Randl, T. Mészöly, and B. Hofer, "Textile reinforcement in ultra high performance concrete-a sustainable material composition," in Proceeding of the SGEM 2017-17th International Multidisciplinary Scientific Geo Conference, pp. 683-694, Vienna, Austria, November 2017.

[20] T. Mészöly, S. Ofner, and N. Randl, "Mechanical properties of glass and carbon textile reinforced UHPC," in Proceedings of the Fib Symposium 2019, pp. 289-296, Kraków, Poland, May 2019. 